\title{
OVERTNESS-COVERTNESS IN ADVERTISING GENDER METAPHORS ${ }^{1}$
}

\author{
MARISOL VELASCO SACRISTÁN* \\ University of Valladolid, Spain
}

\begin{abstract}
This paper aims at demonstrating that weak communication (overt and covert) can have an important influence on the choice, specification and interpretation of ideological metaphors in advertising. We focus here on a concrete type of ideological metaphor, advertising gender metaphor. We present a description of advertising gender metaphors, subtypes (cases of metaphorical gender, universal gender metaphors and cultural gender metaphors) and crosscategorisation in a case study of 1142 adverts published in British Cosmopolitan (years 1999 and 2000). We next assess "overtness-covertness" in the advertising gender metaphors in our sample. In considering this we also look at the conventional-innovative scale of these metaphors, and examine their discrimination against men and women. The intended value of this paper lies in its examination of both weak overt and covert types of communication in relation both to cognitive and pragmatic theorising of metaphor, and, more generally, to theorising advertising communication.
\end{abstract}

Keywords: advertising, gender, metaphor, ostensive communication, covert communication.

1. Financial support for this research has been provided by Grant "Lenguaje e Ideología en la Sociedad del Conocimiento: Análisis de la variedad GÉNERO en córpora especializados monolingües, bilingües y multilingües en inglés, español, francés y alemán" (Reference VA 041A05). Part of this article, mostly from section 3, appears in the articles "A Critical Cognitive-Pragmatic Approach to Advertising Gender Metaphors" (Velasco Sacristán 2005) and "Towards a Critical Cognitive-Pragmatic Approach to Gender Metaphors in Advertising English" (Velasco-Sacristán and Fuertes-Olivera 2006).

* Correspondence should be sent to: Marisol Velasco Sacristán. Universidad de Valladolid. Departamento de Filología Inglesa. Escuela Universitaria de Estudios Empresariales. Paseo del Prado de la Magdalena s/n. 47005 Valladolid. E-mail: marison@tita.emp.uva.es 


\title{
COMUNICACIÓN OSTENSIVA Y ENCUBIERTA EN LAS METÁFORAS DE GÉNERO EN LA PUBLICIDAD
}

\begin{abstract}
RESUMEN. Este artículo tiene como objetivo demostrar que la comunicación débil (ostensiva y encubierta) puede jugar un papel importante en la elección, especificación e interpretación de metáforas ideológicas en la publicidad. Nos centraremos aqui en un tipo concreto de metáfora ideológica, la metáfora publicitaria de género. Presentaremos una descripción de las metáforas publicitarias de género, subtipos (ejemplos de género metafórico, metáforas universales de género y metáforas culturales de género), así como ejemplos híbridos en un estudio de 1142 anuncios publicados en British Cosmopolitan (años 1999 y 2000). A continuación valoraremos el carácter "ostensivo-encubierto" de las metáforas publicitarias de nuestra muestra. Al considerar este aspecto también analizaremos el valor convencional o innovador de estas metáforas y examinaremos su discriminación frente a hombres y mujeres. El valor de este artículo radica en el análisis tanto de los tipos de comunicación débil ostensiva como encubierta en relación tanto con la teoría cognitiva y pragmática de la metáfora, así como, de forma más general, con la teoría de la comunicación publicitaria.
\end{abstract}

Palabras clave: publicidad, género, metáfora, comunicación ostensiva, comunicación encubierta.

\section{INTRODUCTION}

Traditional studies have often presented figurative language as language used for distortion, disguise and concealment. Locke (1961: 105, quoted in Goatly 1997: 105), for example, denounced figurative language as follows: "all artificial and figurative application of words eloquence hath invented, are for nothing else but to insinuate wrong ideas, move the passions, and thereby mislead the judgement, and so indeed are perfect cheat". Due to this distortion it is not strange that for centuries persuaders have used figurative language to maximise their persuasive effect on the audience. Metaphors, for instance, naturally involve a distortion and thus a disguise, a distraction from the immediate impression of the real object (cf. Goatly 1997: 160). They are used to compare things that are apparently different yet have something in common, thus helping the audience to escape their previous way of seeing by looking at something from a different angle (cf. Borchers 2005: 189). Moreover, beyond this epistemological and ontological perspective of metaphors as disguising language we need to concentrate on its ideological side. Indeed the impossibility of non-analogical reasoning brings us face to face with the relation between ideology and metaphor. Metaphors are not a mere reflection of a preexisting objective reality but a construction of reality. Hence they can be used 
to construct reality as a means of maintaining or challenging power relations in society (Goatly 1997: 155). Therefore all metaphors seem to be ideological in origin. As Goatly (1997: 157) argues "probably all metaphors express an ideological substratum of which we are normally unaware". Consequently the choice of metaphors can have both far-reaching cognitive as well as ideological consequences (Goatly 1997: 79). Researchers contend that the presence of metaphor when used for disguise and concealment, especially to prevaricate or avoid responsibility for what one says in influential types of discourse (e.g. political, religion, advertising, etc.) can be an indicator of the so-called "covert communication". In her book Advertising Language: A Pragmatic Approach to Advertisements in Britain and Japan (1994) Tanaka shows how metaphor can be used for covert communication, to make indirect claims for which the advertiser can later avoid responsibility.

Nowadays ideological metaphors are both highly pervasive and latent in advertising. If, as we have seen, metaphors may disguise, mislead and misrepresent, even to a greater extent than ordinary language and, as we will see, they demand a higher level of processing than ordinary language one may wonder why advertisers engage in strategies such as covert metaphors to state controversial claims rather than avoiding them. Therefore a question is raised over the need for covertness in advertising and advertising metaphors in the first place. Indeed recent advertising literature from cognitive and social psychology as well as audience reception studies argue that advertising effects are nowadays subtle and strategies are largely transparent (Bogart 1990; Jones 1997, 1999; de Chenecey 2000; Sutherland and Sylvester 2000; Sutherland 2001; Crook 2004). Yet, even if we accept, as argued by these studies, that nowadays advertising covertness is sparingly used, the question is: "why is still in use?". The answer to this question may well be found in the workings of today mediated advertising persuasion.

Advertising persuasion is vastly different today than it has been for centuries. Media and other forms of technology have altered individuals and cultures and, consequently, the ways we produce and receive persuasive communication. On the one hand, persuasion today is audience-oriented. The addresser (or persuader) does not necessarily have an authoritative position and uses language strategies and visual images to suggest meaning to an audience, but the audience, using its own attitudes and reasoning skills, constructs its own meaning. On the other hand, in today world of mediated persuasion much is left unsaid. As a result, a persuader's argument usually relies less on data and reasoning and more on emotive claims he or she advances (Borchers 2005: 5-6; 22). Persuasion therefore is characterised in advertising by "gentle, mental biasing" rather than "heavy-weight persuasion" (Sutherland and Sylvester 2000: 8) traditionally associated with "double-glazing salesmen" (Tanaka 
1999: 39). This means that traditional "hard-sell strategies" (Kwanka 1993) such as, for example, the use of verbal imperatives (i.e. Buy X. Go and get X right away, etc.) are generally avoided or at least suppressed in the more sophisticated kinds of consumer advertising today. Possibilities for this change include the use of innovative verbal and non-verbal rhetorical figures, which are probably felt to be less aggressive and may be regarded as a transition from hard-selling to soft-selling strategies. In nowadays advertising images containing rhetorical figures may be sufficient to evoke the desire and even stimulate the action that leads to the advertised product or service acquisition and consumption. In some cases the conceptual link of these figures, mostly metaphors and metonymies, is not explicitly expressed at all, but it is to be regarded as an underlying, but nevertheless, conceptual component of the advert - the "missing conceptual link" (Ungerer 2000: 324).

Therefore if, for the time being, we accept "covertness" and probably "weak overt communication" as prevailing features in the modern advertising discourse, we can now proceed to investigate how both examples of weak communication might help to explain the effectiveness, and sometimes the failure, of a particular type of ideologically-loaded figure in advertising: gender metaphors. The discussion will begin in section 2 , by tackling the role of covert communication in advertising. In section 3 we will focus on advertising gender metaphors, illustrating their presence in a sample of 1142 commercial adverts taken from British Cosmopolitan, published between January 1999 and March 2000. Next, in section 4 we will tackle "overtnesscovertness" in the advertising gender metaphors in our sample. In considering this we will assess the "conventional-innovative scale of metaphors" as a determining factor for covertness in advertising gender metaphors. We will then quantify the cases of conventional and innovative examples of the gender metaphors included in our sample, look at their correspondence with covert and overt communicated advertising gender metaphors and examine their discrimination against men and women. Finally, in section 5, we will draw together the various issues raised in the course of this paper, offering an overall conclusion.

\section{COVERT COMMUNICATION IN ADVERTISING DISCOURSE}

The notion of covert communication is not uncontroversial. It seems to be incompatible or even oxymoronic with a view of communication (cf. Crook 2004: 721). As Sperber and Wilson (1995: 30) argue "one tends to think of communication as something done overtly: either your behaviour makes it clear that you are communicating or else you are not truly communicating at all". Yet, despite this "contradictio in terminis" of the term "covert communication" then what other explanation can be accounted for the type of communication or information transmission where the source and his/her informative intentions remain hidden 
and assumptions are made manifest, but not mutually so? (cf. Crook 2004: 720). Other terms used to name this type of communication have been "covert forms of information transmission" (Sperber and Wilson 1995: 30), "covert persuasion" or "propaganda" (Sproule 1994, quoted in Borchers 2005: 269).

According to Bencherif and Tanaka (1987; quoted in Tanaka 1999: 41) covert communication opposes ostensive (or overt) communication and takes place when the speaker's informative intention is not made mutually manifest. They define it as follows:

Covert communication: a case of communication where the intention of the speaker is to alter the cognitive environment ${ }^{2}$ of the hearer, i.e. to make a set of assumptions more manifest to her ${ }^{3}$, without making this intention mutually manifest.

This notion of covert communication works within a relevance-theoretic framework, which is an expansion of Sperber and Wilson's seminal work on ostensive-inferential communication. This is in direct opposition to the code model view of communication, which advances the idea of communication as the mere transmission of information. Relevance theory constitutes an attempt to characterise communication as achieved by means of the recognition of intentions, the consequent mutuality of the cognitive environment and the operation of inferential processes (Crook 2004: 721). In this sense, the distinction between informative intention and communicative intention, the audience's search for optimal relevance and its interest in cost-effectiveness are of crucial significance in characterising covert

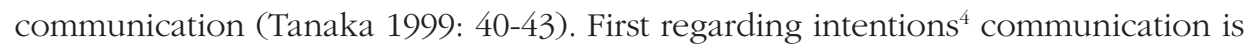
seen as involving an informative intention which is embedded within a secondorder communication intention (Crook 2004: 718). Both types of intention are defined by Sperber and Wilson (1995: 58, 61) as follows:

Informative intention: to make manifest or more manifest to the audience a set of assumptions.

Communicative intention: to make it mutually manifest to audience and communicator that the communicator has this informative intention.

"Overt communication" consists of the revelation of these two layers of information whereas covert communication hides the informative intention by making assumptions more manifest, but not mutually so. In other words, the

2. Cognitive environment is defined by Sperber and Wilson (1995: 39) as a set of facts, which are manifest, i.e. mentally representable and acceptable as true or probably true.

3. Bencherif and Tanaka assume that the addresser is male and the addressee is female.

4. According to Sperber and Wilson (1995: 31) intentions are mental representations capable of being realised in the form of actions. 
speaker does not publicise his/her informative intention when he/she believes that revealing it would have an adverse effect on its fulfilment (Tanaka 1999: 42).

Second, as opposed to ostensive communication, covert communication does not bear a guarantee of optimal relevance. According to Smith and Wilson (1992: 5) "An utterance, on a given interpretation, is optimally relevant only and only if: a) it achieves enough effects to be worthy of the hearer's intention; b) it puts the hearer to no gratuitous effort in achieving those effects". In covert communication the hearer does not have the speaker's guarantee of optimal relevance to guide his/ her interpretation, but other stimuli to overcome this deficiency. The communicator relies on the addressee noticing certain non-linguistic stimuli, given the way in which his/her general cognitive system is organised. In this sense, sex and food are typical stimuli which draw the audience's attention. Sperber and Wilson (1995: 151-155) argue that this is so because human beings are more susceptible to some cognitive phenomena than to others, as cognition is designed to pick out relevant phenomena and process them in the most efficient way. The notion of relevance is thus valid in determining which non-linguistic stimuli are likely to be processed, and in what way (cf. Tanaka 1999: 22, 41).

Third, since processing information requires effort, the request to undertake this task has to be accompanied by reward. By requesting the addressee's attention, the communicator indicates that he/she has reason to believe that is providing relevant information which will make the addressee effort worthwhile (Sperber and Wilson 1995: 124-125; Tanaka 1999: 20). The hearer often does not get his/ her reward entirely through inference in covert communication, for the speaker exploits the fact that humans get a kind of pleasure out of processing the above mentioned stimuli. These are likeable as they are entertaining and amusing.

In addition, it may be argued that covert communication and weak (overt) communication are very similar. Both shift responsibility for certain interpretations away from the communicator and towards the addressee and they are only distinguished from one another in terms of mutual manifestness, which is a gradable or comparative notion, not an absolute one. In this sense, those assumptions merely made mutually manifest (or where the degree of manifestness is extremely low - perhaps one arising from the use of an image) are at a practical level very similar to those communicated overtly (Crook 2004: 733). All this seems to suggest that both weak ostensive and covert communication are variants of a similar type of communication where there are different clines from pure overt ostensive communication to pure covert communication.

Tanaka (1999: 36) decides to consider advertising in terms of "covert" rather than "ostensive" communication arguing that "covert communication is a response to the inter-related problems which advertisers face in their task of persuading or influencing". Advertising is, indeed, typical of a situation in which there is a low 
level of trust ${ }^{5}$ and social cooperation between advertisers and their audience. The advertiser's task is to make the audience believe something about a product without her (i.e. the addressee) distrusting him (Tanaka 1999: 40). This leads to a variety of strategies on the part of the advertiser. Covert communication is one of these (Tanaka 1999: 40). According to Tanaka (1999: 43) the advertiser engages in covert communication for two main purposes: (1) to try to make the addressee forget that the advertiser is trying to sell her something and (2) to avoid taking responsibility for the social consequences to certain implications arising from advertisements. Regarding the first purpose when advertisers use covert communication the audience "may have a feeling of solidarity with the advertiser for being daring, interesting, or 'in the know' [...]". (Tanaka 1999: 58). Concerning the second purpose, when the advertiser modifies the mutual cognitive environment of the addressee with regard to certain concepts such as "sex" or "snobbery" he wishes to gain advantage from associating his product with enhanced sexual performance, but at the same time does not want to be held responsible for having done so. The advertiser hopes that the audience will be responsible to recover these assumptions on their own responsibility.

In short, Tanaka (1999: 58) argues "covert communication, if and when it works allows the advertiser to have his cake and eat it". In our view, its use in advertising corresponds to two concrete reasons: (1) to meet the first two criteria of the AIDA formula and (2) to improve social relations with the audience (Tanaka 1999: 62). In this sense, we claim first that covert communication strategies serve both as attention-grabbing and interest-raising devices, because of its puzzling, amusing and entertaining nature, thus satisfying the first two steps of the well-known AIDA formula (Attention-Interest-Desire-Action), which is not only recommended in practical guidelines for advertising copywriters, but also used in the pragmatic interpretation of adverts (Vestergaard and Schrøder 1985; cf. Ungerer 2000: 304); and second as a social enhancer, strengthening the social bond between the advertiser and the consumer, enhancing the credibility of the persuader while leading to an attitude change in the audience. The advertiser, on the one hand, wishes to use problematic areas of particular sensitivity (i.e. sex, gender, etc.) as a means of cultivating intimacy, escape any responsibility for doing so and avoid negative social reactions emanating from the public. The hearer, on the other hand, can benefit from becoming more involved in the process of communication,

5. Crook (2004: 726), in his refinement of Tanaka's notion of covert communication in advertising, argues that trust in advertising is not a black and white situation. Where claims are cognitively consistent with the audience's beliefs, trust is less important; where claims risk consistency, and therefore disbelief, trust is more important. He prefers the notion of "scepticism" when referring to the way advertisers address an audience in today advertising. 
receiving a reasonable pay-off for his/her efforts at interpretation in terms of the number of contextual effects produced, and can eventually accept or reject the advertiser's message.

\section{ADVERTISING GENDER METAPHORS}

Rhetorical figures have traditionally been considered aesthetic devices found exclusively in literary language. However, it is clear that its use is not limited to literature as they are also found in other fields. Advertising is no exception to this. Indeed, figures of speech are widely employed in the discourse of advertising. Advertisers tend to present the positive aspects of the object to customers in the hope of selling it to them. This can be done rather explicitly by verbalizing how good, exquisite, etc. the advertised object is for the customer. Yet, as we saw in the introduction, sophisticated advertising prefers more indirect strategies, and perhaps the most important one among them is to establish a metaphorical link with a domain conventionally representing the desired quality (Ungerer 2000: 325).

Apart from the aesthetic value traditionally attached to advertising metaphors recent research has contributed new interesting insights into the discursive, cognitive and pragmatic role played by them (Deighton 1985; Durand 1987; Howard 1990; Forceville 1991, 1994, 1996, 1999, 2000, 2002; McQuarrie and Mick 1992, 1996, 1999, 2003; Dingena 1994; Leigh 1994; Scott 1994; Zaltman and Coulter 1995; Velasco Sacristán 1999, 2003, 2005; McGuire 2000; Ungerer 2000; Cortés de los Ríos 2001). Findings have shown that advertising metaphors can have different discursive instantiations, they can establish different links between domains established by verbal and non-verbal elements of adverts, enhance ad recall and produce more positive attitudes (cf. McQuarrie and Mick 2003).

Indeed from a discursive, cognitive and pragmatic point of view the role of metaphors in advertising can hardly be underestimated. On the one hand, the conceptualisation of the advertised item or service is usually expressed by either verbal or non-verbal instantiations of conceptual metaphors that act as a "link between the domain of the advertised item and other domains" (Ungerer 2000: 321). On the other hand, advertisers produce metaphorical utterances to invite their audience to process the utterance. In doing so, the audience is made to see resemblances between the promoted product or service and the object or property featured in the metaphor. However, the audience takes part of the responsibility in deriving further assumptions about the object which it associates with the product or service (Tanaka 1999: 90).

Taking this discursive cognitive-pragmatic account of advertising metaphors as a starting point for reflection we assume here the following basic ideas on advertising gender metaphors: (i) advertising gender metaphors have verbal, non-verbal, or 
multimodal realisations in discourse; (ii) advertising gender metaphors are ideological metaphors in which the conceptual mapping(s) that is (are) projected from the source to the target domain may create and/or reflect some kind of discrimination against men or women; and (iii) advertising gender metaphors have the potential to give rise to sexist interpretations that are often covertly or weakly overt communicated (Velasco Sacristán 2003, 2005).

First, regarding the discursive realisation of advertising gender metaphors we have considered the fact that the source and target need not necessarily manifest themselves in the same medium and/or code. This is important, for it means that a metaphorical domain (whether a source or a target) can, in principle, occur in a wide variety of modes, as long as the following conditions are fulfilled: (1) it is accessible to at least one of the senses; (2) it is conceptualisable as a metaphorical domain to be construed as a source or target (this also entails, of course, that it must be linkable with its complementary domain - either source or target); (3) the domain to be construed as a source evokes orientations that can be mapped onto the target in a relevant manner (Forceville 2002: 217). If this is accepted, three general categories of metaphors realisations can be identified for advertising metaphors: verbal, pictorial ${ }^{6}$ and multimodal (Forceville 1996, 2002), which can accommodate even more specific subtypes: pictorioverbal, verbopictorial, etc. Second, concerning advertising gender metaphors as ideological metaphors we have born in mind that ideological metaphors conceal underlying social processes and determine interpretation. With them metaphor producers take advantage of the mapping process to make sure that not only ideational meanings are mapped onto the target domain but also to introduce different interpersonal attachments that can create and/or reflect some kind of discrimination against men and/or women. They are typical examples of asymmetrical metaphors that are not intended as metaphor by the speaker but interpreted as such by the hearer, or, conversely, not intended as metaphors by the speaker but interpreted as such by the hearer (Goatly 1997: 127). Third, advertising gender metaphors as communicative devices have correspondences that can give rise to sexist interpretations. They are used by advertisers to introduce a value system on gender that often activates and imposes negative "sexist" values by means of covert and weak overt communicated assumptions. In doing so the advertiser

\footnotetext{
6. Although the very idea of a pictorial metaphor is controversial (Forceville 1996; Cabe 1999) we argue for the idea that there are pictorial metaphors. Although pictures do not possess propositional content, as utterances do, it is obvious that pictures, like verbal utterances, are made by agents and in this sense in the case of a pictorial metaphor, the artist succeeds in getting his or her audience to appreciate some point or to think about one thing by means of presenting a picture that is about something utterly different" (McGuire 1999: 299). We therefore conclude that metaphorical processes can and do play a role in advertising images of various kinds. They produce the cognitive effect of inviting the viewers to see a link between depicted entities of various kinds, and the latter is to be understood in terms of the former (Forceville 1996; cf. Velasco Sacristán 2005: 248).
} 
does not leave the interpretation process unattended thus retaining a degree of control over the audience's interpretation while shifting responsibility for that interpretation away from him/her and towards the audience. There may also be variation in awareness of the use of the conscious processes involved in encoding some advertising gender metaphors as compared with other cases. In those cases of covertly communicated advertising gender metaphors it is likely that the metaphor producer may or may not wish the metaphor receiver to be aware that there is a covert activation and imposition of negative "sexist" values (nor indeed may he or she be aware of this himself or herself). However, as Forceville (1996: 65ff) argues, if metaphors are regularly used in advertising, as he demonstrates, then it should be the case that these usages are highly intentional.

In the discourse of English advertising there are three different types of gender metaphors that are located at different points of the "universality-culture specificity continuum" of advertising gender metaphors: "cases of metaphorical gender", "universal gender metaphors" and "cultural gender metaphors". These types, rather than appearing in isolation in single ads, very often co-occur, giving rise to a complex network of gender relations within numerous ads (cf. Velasco Sacristán 2003, Velasco Sacristán 2005).

\subsection{CASES OF METAPHORICAL GENDER}

On one end of the "universality-culture specificity continuum" there are cases of metaphorical gender, which are the most culturally-specific type of gender metaphor. In English, instances of metaphorical gender take place when an animate object is the grammatical subject of a verbal or mental process. This can have a verbal realisation ${ }^{7}$ (only in languages with a semantic gender), a pictorial realisation (in any language), or a multimodal realisation (verbopictorially or pictorioverbally).

Advertisers extend the metaphorical gender to develop the so-called "commoditisation process" (Borchers 2005: 27) or "theory of the metaphorical commodification" (Sánchez Corral 1991, 1997) that is used to personify the promoted product or service. In this metaphor the nonhuman entity of a commodity is understood in terms of a person (often the consumer) and the different human features, motivations and activities related to this person, giving rise to the metaphor "The commodity is the consumer", which is indeed an example of the ontological metaphor "items to sell are people" (Kövecses 2002: 59) that evokes in the reader the same attitudes and feelings that they have in connection with a person,

\footnotetext{
7. This concrete instantiation of the metaphorical gender in advertising English has traditionally been considered as an illustration of Halliday's grammatical metaphor (Talbot 1992). Yet, in our view, it can be a more complex type of metaphor as it often goes beyond the limits of grammar, being reinforced in the discourse of advertising by visuals.
} 
consumer who is often constrained by a part-for-whole metonymy (i.e. "sex" for "person") that is related to the commodity by yet another metonymic experience (i.e. getting commodities as a result of buying them as consumers). Usually the verbal pronouns and/or context provide us with sufficient cues to decide which construal is appropriate. In the following advert for "Eva Lingerie" (Plate 1), we can see the metaphor "The advertised lingerie (commodity) is a woman (consumer)":

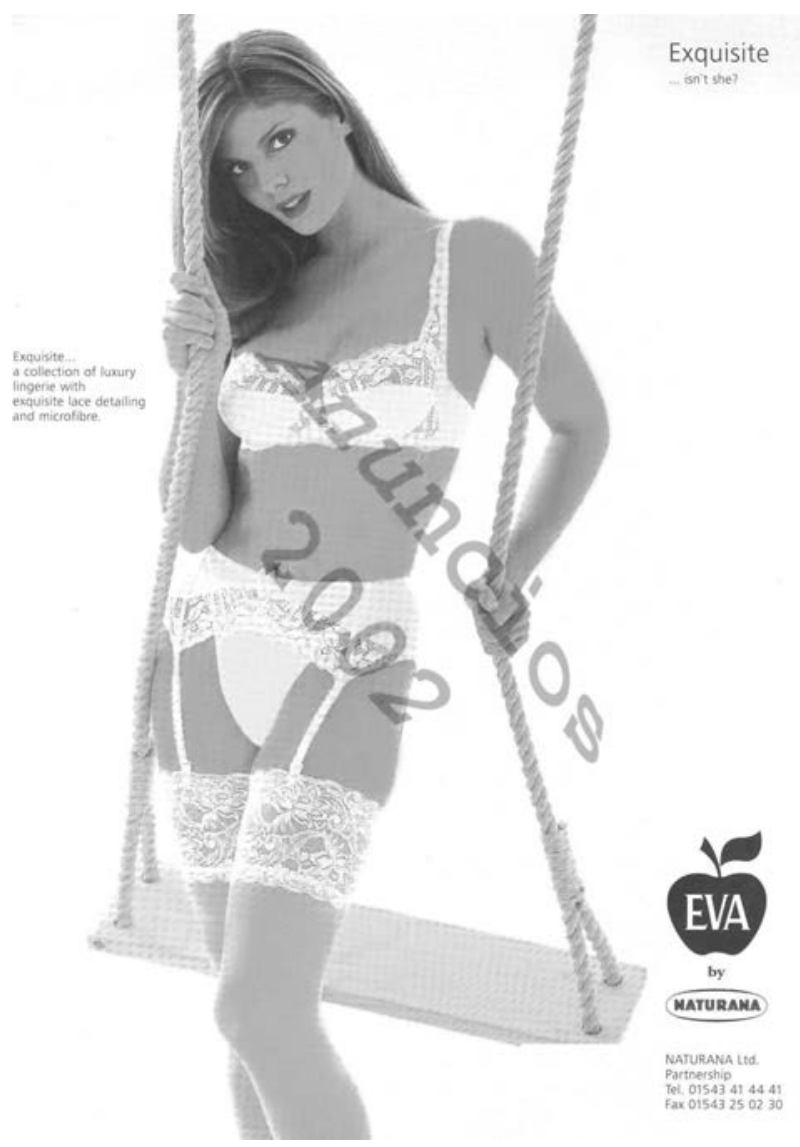

Plate 1. The advertised lingerie (commodity) is a woman (consumer)

The ad promotes "a collection of luxury lingerie with exquisite lace detailing and microfibre". For that purpose it features in a sexy young woman wearing the advertised product and the slogan "Exquisite... isn't she?". The use of "she" here 
seems to point to the lingerie to convey definitional attributes of a person (i.e. personal name, etc.) and the associate attributes of "womanhood" (i.e. sexiness, exquisiteness, etc.).

In summary, advertisers use cases of metaphorical gender to develop the socalled "metaphorical personification of the commodity" (Sánchez Corral 1991, 1997) or "commoditisation process" (Borchers 2005: 27) that adds value to the advertised commodity by transferring to it human attributes and behavioural actions. This pervasive personifying tendency of ads may be, on the one hand, a tool for synthetic personalisation - addressing a mass audience as though talking to them intimately as individuals (Fairclough 1989: 217ff) and, on the other hand, a representation for the ideology of consumer capitalism (Dyer 1984: 77-84) as we exchange real political power for purchasing power, and products become powerful and considerate agents which remove our problems (Goatly 1997: 303). Personification thus builds user-friendliness or helpfulness.

\subsection{UNIVERSAL GENDER METAPHORS}

Much metaphorical thinking arises from recurring patterns of embodied experience that are universal or at least shared across many cultures (Lakoff and Johnson 1980; Lakoff and Kövecses 1987; Kövecses 1990, 1999, 2002). In this sense metaphors are regarded as part of people's internal mental representations. The embodied nature of metaphorical thought and language use generally assumes that people create embodied metaphorical representations from their phenomenological experiences of their body and their sensorimotor interactions with the physical world. People's metaphorical understanding of certain abstract concepts (i.e. emotions, power, etc.) are intimately tied to image schemas that partly arise from recurring bodily experiences (Gibbs 1999: 151). Image schemas are prelinguistic cognitive structures (e.g. "container", "part-whole", "front-back", "up-down", "source-path-goal", "link", "centre-periphery"), often found as structural patterns used as source domains for numerous metaphors (Lakoff and Turner 1989; Lakoff 1993) giving rise to the socalled "image schema metaphors" (Kövecses 2002: 36).

Image schemas are extremely productive in terms of social structuration. They therefore play a very important role in our understanding of the power of discourse and social institutions. Indeed the kinaesthetic image schemas of "compulsion" (a force which travels along a trajectory at a certain speed and moves or carries an object or person along in its path), "blockage" (a force vector encountering a barrier and then taking any number of possible directions) and "containment" (an elaboration of the blockage schema wherein the blockage is continuous so as to separate "inside" from "outside") (Johnson 1987) lie at the root of our everyday 
conception of power. Persuasive discourses are, therefore, awash with metaphors sustained in image_schemas.

In advertising spatial metaphors based on image schemas are commonly used to convey power and to construct gendered spaces. In the 70's and 80's femininity and feminine spaces were constructed through submission with a decrease on the size of the territory controlled. Nowadays, there have been changes in the level of content (i.e. more men in kitchens or holding babies, more women in business suits) while image schemas have been largely unchanged (Umiker-Sebeok 1996). This seems to prove that the use of image schemas in advertising is, largely due to our awareness, more difficult to alter than content (Umiker-Sebeok 1996).

Furthermore, in the discourse of advertising metaphors sustained in image schemas give rise to correlated non-spatial inferences that help to construct asymmetrical relations on the basis of the axiological value that underlies image schemas (Krzeszowski 1990, 1993). In the schema "up-down", for instance "up" is related to power, control, goodness and "down" to powerlessness, submission, badness (cf. Krzeszowski 1990, 1993; Cortés de los Ríos 2001). It has been pointed out that various spatial image schemas are bipolar and bivalent. Thus, "whole", "centre", "link", "balance", "in", "goal", "front" are mostly regarded as positive while their opposite, "not whole", "periphery", "no link", "imbalance", "out", "no goal", and "back" are negative (Kövecses 2002: 35).

In advertising metaphors based on different image schemas are often used to display men/women as powerful people (at the front of the page, usually on the right hand side, etc.) triggering the spatial discrimination of men or women. Universal gender metaphors may be defined as those metaphors based on kinaesthetic image schemas, especially those of Compulsion, Blockage and Containment, used to locate men or women in the sociocultural, political and economic setting, hence discriminating against one sex or the other. They are, all in all, useful to polarise the world (as portrayed in the ad) as "the male versus the female".

A typical example of this type of gender metaphor in advertising is "A man/ woman is a primary person" mostly based on the binary schemas of "up-down", "front-back", "first-second", and "big-small". The advert for "ZM magazine" (Plate 2) contains a typical manifestation of one case of the above conceptual metaphor: "A man is a primary person".

This double-page advert reserves the left page for the headline "you deserve better sex" and the right page for a representation of the advertised magazine's front page together with the slogan Give him ZM. Feel him better. The picture of the left page portrays a young man and a young sexy woman. The woman, who is at the back, sitting with her legs crossed and her features blurred, is only wearing an unbuttoned shirt and black lingerie. This naturalness of the "first/front" to "second/ 


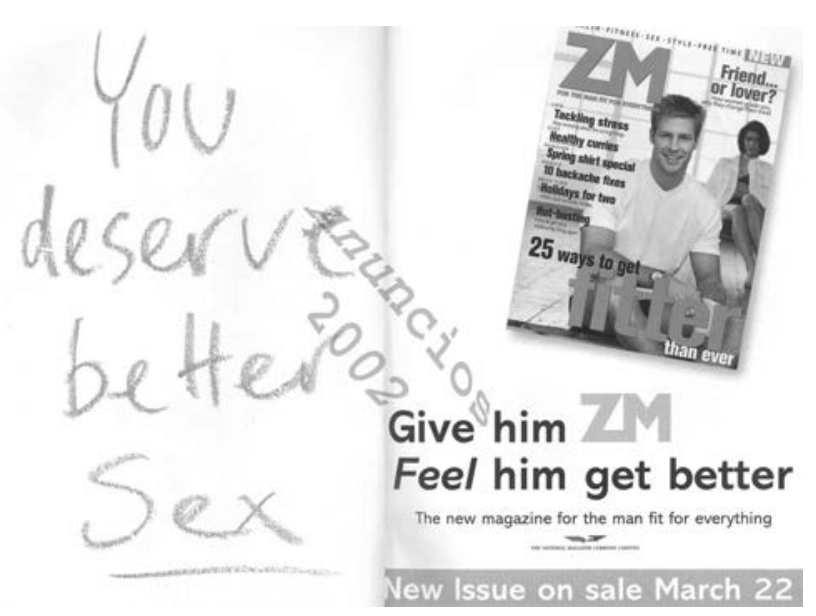

Plate 2. A man is a primary person

behind" mapping follows the same general cognitive constraints previously introduced with respect to the use of kinaesthetic image schemas to construct powered and gendered spaces in advertising.

All in all, advertising universal gender metaphors are denigratory insofar as they are based on image schemas that are largely and probably "covertly" beyond our awareness, more difficult to alter than other content-based denigratory devices, and reinforced by the axiological value typically attached to image schemas. The three directional binary level of "right-left", "above-below" and "front-behind" seems to be of most salience in the metaphorical conceptualisation of advertising universal metaphors (cf. Umiker-Sebeok 1996; Velasco Sacristán 2003).

\subsection{Cultural Gender MetAPHORS}

One of the problems with the idea that conceptual metaphors are determined by our preconceptual experiences is that the use of discriminatory metaphors might then be explained - and perhaps even excused - by our physical limitations. This is the reason why some authors have turned away from a search for universal metaphors and have instead begun to stress the cultural dimension of metaphor (Holland and Quinn 1987; King 1989; Quinn 1991; Emanatian 1995, 1999; Matsuki 1995; Yu 1995).

According to Quinn (1991), conceptual metaphors follow from cultural models that are already in place. These cultural models are defined by Holland and Quinn (1987: 4) as follows: "presupposed, taken-for-granted models of the world that 
are widely shared by the members of a society [...]". Since metaphors create a link between cognitive models, we can define cultural gender metaphors as those metaphors that rest on asymmetrical cultural practices (e.g. androcentrism, patriarchy, etc.) primarily based on gender stereotypes ${ }^{8}$ that result in discrimination against men or women (Velasco Sacristán 2003). In general terms, cultural gender metaphors tend to understand human beings in terms of objects, animals, or stereotypical human features. Metaphors of the first two types (i.e., objects and animals) are explained in terms of the so-called "great chain metaphor", as proposed by Lakoff and Turner (1989: 170ff). The GREAT CHAIN is a cultural model ${ }^{9}$ defined by attributes and behaviour which typically apply to each form of being (humans, animals, plants, complex objects, and natural physical things) in a hierarchy. For example, animals are characterised by having instinctual attributes and behaviour (Lakoff and Turner 1989: 170-171). The "great chain metaphor", as proposed by Lakoff and Turner, basically consists of a very abstract metaphor, THE GENERIC IS SPECIFIC metaphor, whose mappings are guided or motivated by two entrenched cultural models, namely, "the basic chain of being" and "the nature of things" (which are themselves combined into "the extended great chain"), and by the pragmatic maxim of quantity. There is no space here for a detailed exposition of each of these ingredients, but "the great chain metaphor" explains a large number of mappings in which lower-order forms of being and their attributes can be mapped onto the higher forms of being, and their usual behaviour or functioning are mapped onto human bodies and people, etc. (Barcelona Sánchez 1997: 36).

We have so far characterised cultural gender metaphors as those sustained in gender stereotypes rooted in our cultural traditions. Their discrimination stems from the denigratory value of gender stereotypes. Figure 1 shows the scale of sexist denigration of gender stereotypes that underlies the above described "great chain metaphor".

In advertising English cultural gender metaphors discriminate when men or women are understood in terms of the lower elements described in the basic chain of being (i.e. animals and objects) or when men or women, although seen as human beings, are defined by stereotypical denigratory features. From low to high discrimination we find the following three subtypes of cultural gender metaphors: "A man/woman is a person (with stereotypical features)"; "A man/ woman is an animal (with stereotypical features); and "A man/woman is an object

\footnotetext{
8. A gender stereotype is a generalised and relatively fixed image of a person or person belonging to a particular group. This is formed by isolating and exaggerating certain features - physical, mental, cultural or occupational, personal and so on which seem to characterise the group (Pauwels 1998: 97).

9. Yet some authors like Kövecses (2002: 126) think that the Great Chain Metaphor is a folk theory that can be found in many cultures and it may well be universal.
} 


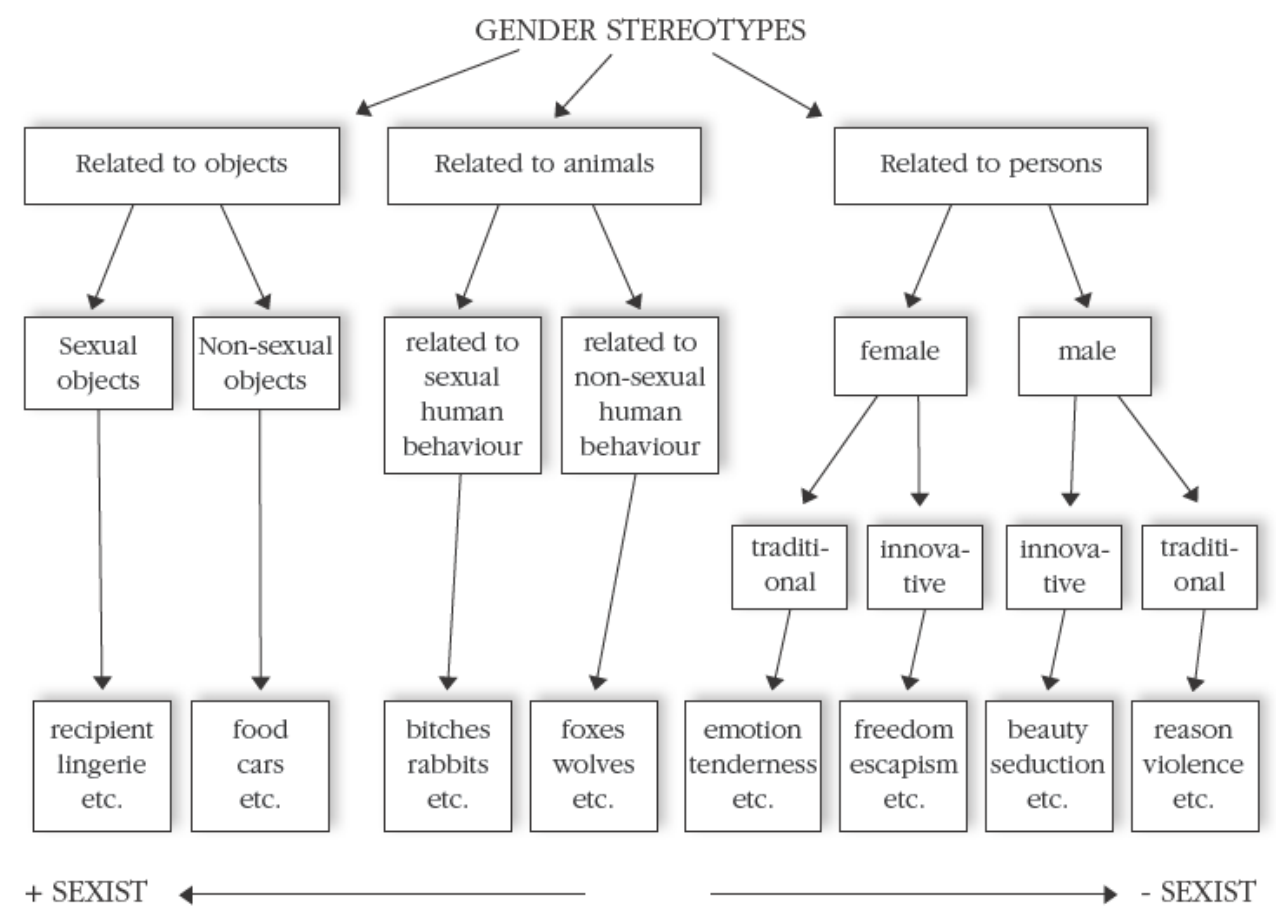

Figure 1. Velasco Sacristán, Fuertes Olivera and Samaniego Fernández (2005: 167)

(with stereotypical features)". The third subtype is indeed a metonymy rather than a metaphor. In English advertising a typical case of this subtype of cultural gender metaphor is the metaphor "A man/woman is a sexual object" which usually equates the product or service promoted to a sexual entity, usually categorised as food ${ }^{10}$ or an object that resembles the male or female sexual organs (i.e. a container, an item with a phallic shape, etc.). The adverts of "Aubade" (Plates 3 and 4) contain examples of one of the above conceptual metaphors "A woman is a sexual object".

The advertisers show a faceless nude woman, wearing only lingerie. The fact that both women are faceless and nude wearing the lingerie advertised seems to highlight their role as sexual objects, without the identity and uniqueness faces and names offer to human beings. Moreover, the close-up of the lingerie advertised seem to suggest the metonymic reduction of women to their underwear, thus probably emphasising their need to enhance their natural look with seducing lingerie. In

10. In many cultures sexual women are classed as food and "to eat" is used as a euphemism for "to copulate" (Emanatian 1995, Emanatian 1998). 


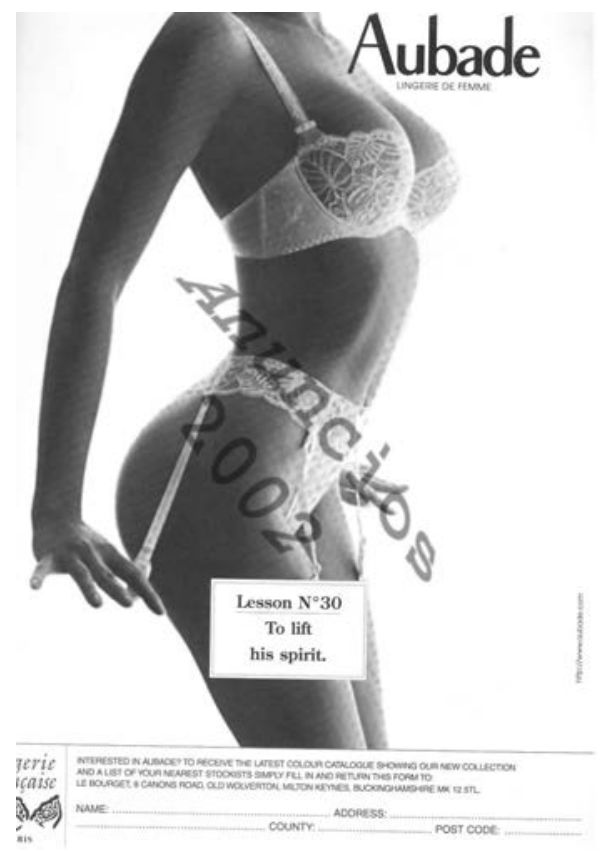

Plate 3. A woman is a sexual object

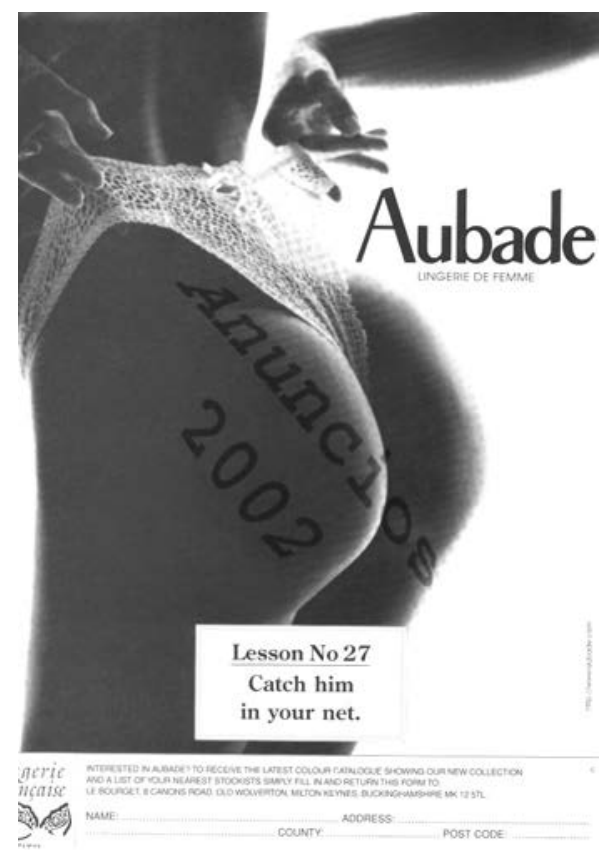

Plate 4. A woman is a sexual object

addition, the fact that the lingerie advertised is useful, not only in its literal sense to dress a woman, but to enhance her sexual performance also appears to introduce discrimination against men. As suggested by both adverts, men become objects of passive consumption when women wear sexy lingerie. They can then be caught, like a fish, in a woman's net (G-string) and helped in getting full erections, thus also apparently suggesting that they need extra help there.

In short, cultural gender metaphors hinge upon stereotypical relations to create asymmetrical gender relations in different conceptual metaphors (mostly instances of the "great chain metaphor") that involve stereotypical denigratory references to human beings, animals or objects). The limiting and demeaning stereotypes that sustain these metaphors result in non gender-neutral metaphors that discriminate against one sex or the other.

\subsection{CROSS-CATEGORISATION OF ADVERTISING GENDER METAPHORS}

The above described gender metaphors rarely appear in isolation in advertising English. Very often metaphorical gender instances and universal gender metaphors 
take on a stereotypical background and some cultural gender metaphors contain discriminatory image schemas, giving rise to hybrid types of advertising gender metaphors (i.e. universal-cultural gender metaphors, etc.).

In short, as illustrated above, there appears to be three different gradient levels of universality-specificity in advertising that go from the most universal type, an image schema metaphor (i.e. universal gender metaphors) to the most specific type, a personification (i.e. cases of metaphorical gender) with an intermediate type made up of examples of "the great chain metaphor" and a metonymy (i.e. cultural gender metaphors). This supports Gibbs' (1999) "distributed perspective", according to which the physical world is not separate from the cultural one in the important sense that what we see in the physical world is highly constrained by our cultural beliefs and values. It also proves that, as Cook (1992: 52) argues, there are three levels of specificity in the advertising environment of an ad: the cosmic world, the social world, and the sexual world of the commodity.

\section{OVERTNESS-COVERTNESS IN ADVERTISING GENDER METAPHORS}

In assessing the "covert-overt" scale of the advertising gender metaphors in our sample we have considered the criteria we introduced above (see section 3) to differentiate between overt and covert types of communication within a relevancetheoretic framework, namely, the distinction between informative intention and communicative intention, the audience's search for optimal relevance, and its interest in cost-effectiveness. We have assumed that covert gender metaphors are those in which the metaphor producer's informative intention is not given, there is no optimal relevance and the interpreter uses other stimuli to make the metaphor cognitively relevant and as a reward to compensate his/her processing effort in interpretation.

Before we present the number and percentage of overt and covert advertising gender metaphors in our sample, let us illustrate with two samples, one of an overt communicated gender metaphor and one of a covert communicated gender metaphor how these criteria were satisfied in our study (see Plates 5 and 6).

In the advert for "Wonderbra" (Plate 5) the image (a waist-up picture of the supermodel Adriana Karembeu modelling the product) and the slogan ("I can't cook, who cares?") in the centre of the ad, next to the advertised bra as if it were a quotation, invite the reader to understand and perceive the advertised bra not in its literal sense but in terms of a person (consumer) defined by her sex, a woman which is a typical example of the ontological metaphor "items to sell are people" which constitutes a case of metaphorical gender as described above (see Section 3). In this metaphor, "The advertised bra is a woman", the 


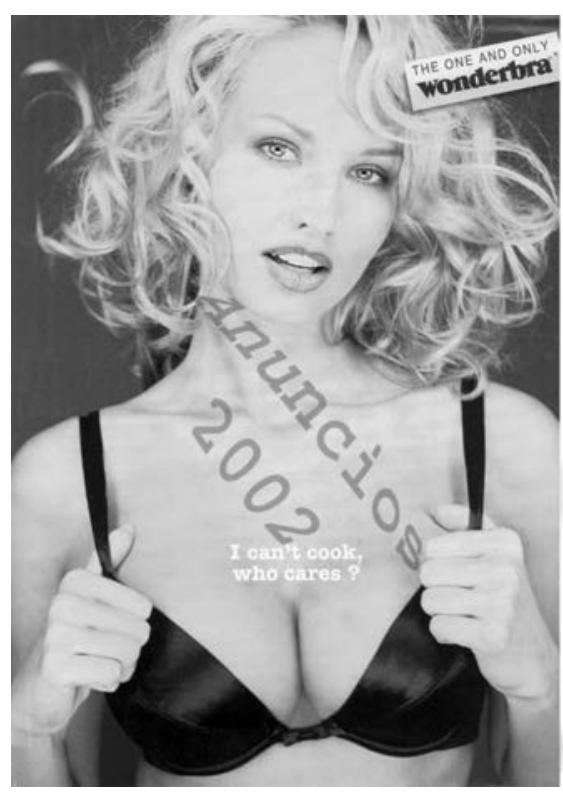

Plate 5. Items to sell are people

following features occurring in the same domain "a woman" could be mapped onto the target domain:

1a) a woman has a personal name

2a) a woman is elegant

3a) a woman is sexy.

Other features that could be listed for a "woman" on the basis of the content of the slogan are:

4a) a woman can speak

5a) a woman is related to a domestic setting/kitchen.

One or more of these features are mapped onto the domain of the "advertised bra". This matching process involves the foregrounding, adoption or modification of certain features in the target domain, we get something like:

1b) the advertised bra has a name (i.e. brand name)

2b) the advertised bra is elegant

3b) the advertised bra is sexy 
4b) the advertised bra speaks for itself

5B) the advertised bra is a garment worn in a domestic setting/kitchen.

In the matching process we observed that "the consumer's personal name" from the source domain became "the commodity's brand name". Similarly, the human ability to speak was transformed into the metaphorical ability attributed to some inanimates to speak for themselves. Finally, the location of women in domestic settings/kitchens became the garment worn in domestic settings/ kitchens. At this stage we realised that some of the mappable features were more widely shared, obvious, and less ambiguous (i.e. $1 \mathrm{~b}, 2 \mathrm{~b}$ and $3 \mathrm{~b}$ ) than others that were more ambiguous, more idiosyncratic, and weakly implicated (i.e. $4 \mathrm{~b}$ and 5b) and concluded that this was due to the distinction between strong and weak implicatures, as described by Sperber and Wilson. ${ }^{11}$ It seems clear that in Plate 5 the advertiser intended to communicate a range of assumptions (here the features mapped from source onto target domain) and communication succeeded when the addressee recovered some of the correspondences within the range (1b, $2 \mathrm{~b}$ and 3b). Yet the addressee was somehow also invited to recover the other mappings in the range ( $4 \mathrm{~b}$ and $5 \mathrm{~b}$ ). Since we did not know the addressee of the metaphor, we could not be sure which of these projections, or which others, he/she would, to some extent, vary in deciding which features were to be projected and may come up with still others.

We concluded that this was an overt advertising gender metaphor as in the producer's informative intention was clear (the commodity is to be perceived in terms of the attributes and behaviour of the consumer), but with some doses of weak communication since the addressee had to recover some weakly implicated assumptions and had difficulties in interpreting the correspondence or implicature of $5 \mathrm{~b}$, the most weakly implicated of all. It seems that an attitude, an emotional perspective, was built by it. We can assume that the advertiser wanted to convey a negative evaluation concerning women, as it helps to maintain a mistaken assumption regarding women's typical behaviour as related to domestic settings/kitchens, perhaps as kitchen slaves to men. Yet, and as it inferred by the slogan, women can overcome this sort of slavery if they wear the advertised bra to enhance their sexy appearance. Therefore we can see that the addressee had optimal relevance to

\footnotetext{
11. Metaphors rely for their effectiveness on both explicatures - explicitly communicated assumptions - and implicatures (Sperber and Wilson 1995: 182). More specifically, "an explicature is a combination of linguistically encoded and contextually inferred conceptual features. The smaller the relative contribution of the contextual features, the more explicit the explicature will be, and inversely" (Sperber and Wilson 1995: 182). Implicatures can be weak or strong. Weak implicatures are less widely shared, less immediate, ambiguous, perhaps more idiosyncratic, whereas strong implicatures are widely shared, immediate, reliable and less ambiguous (cf. Sperber and Wilson 1995: 193-202).
} 
guide his/her interpretation with regard to the strongly communicated implicatures but not in the case of the most weakly communicated ones. The processing effort involved in interpreting those is probably offset by the contextual effects produced by the use of a rather conventionalised, ${ }^{12}$ explicit (and therefore "overt") picture of the attractive image of the model Adriana Karembeu who is scantily clad, has a strong sexual appeal and conforms to a very narrow standard of beauty. Apparently both men and women are drawn to attractive images of models (Messaris 1997). Therefore the visual image of the picture, although not needed to understand the advert, acts as a reward to compensate for the addressee's effort in interpreting weakly communicated assumptions of the metaphor (cf. Velasco Sacristán 2005: 229-234).

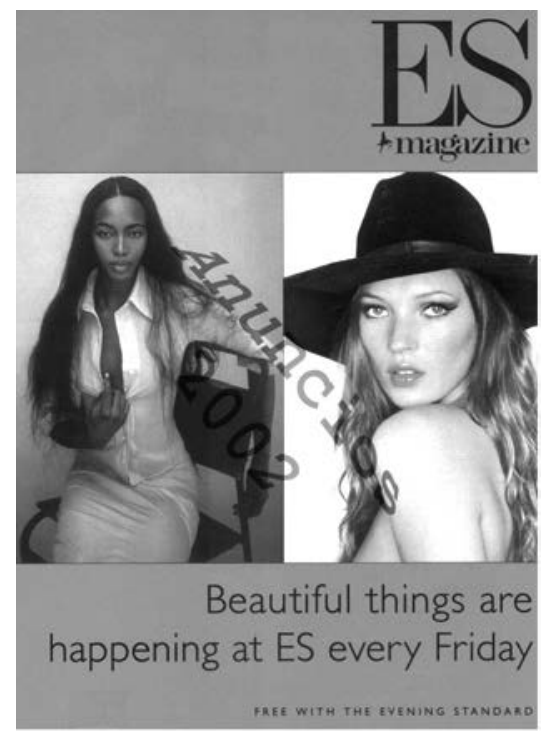

Plate 6. Women are things

In the advert for "ES Magazine" (Plate 6), the image (two pictures of the supermodels Naomi Campbell and Kate Moss, the former wearing an unbuttoned dress and the latter naked wearing a hat) and the slogan "Beautiful things are happening at ES every Friday" seem to invite the reader to understand and perceive

12. As Crook (2004: 728) argues "the use of a sexual image is very much tied up with the nature of the product as something promoting or aiding physical beauty and/or attractiveness to others [...]". 
"women" (supermodels) not in its literal sense but in terms of "things" (those events happening at ES every Friday) thus giving rise to the following cultural gender metaphor: "Women are things". In this metaphor the following features occurring in the source domain "things" could be mapped onto the target domain:

1a) things (events) are happening at ES every Friday

2a) things (events) are beautiful.

In the matching process, after foregrounding, adapting and modifying these features we get something like:

1b) women are portrayed at ES every Friday

2b) women portrayed at ES are beautiful/sexy women (supermodels).

In this matching process we observed that the events happening at ES every Friday became "women" and "beautiful events" from the second mapping became "beautiful/sexy women/supermodels" like the ones portrayed in the pictures: sexually attractive and again conforming to a very narrow standard of beauty. At this stage we realised that both mappable features were very weakly implicated, thus being very ambiguous and idiosyncratic. Consequently in Plate 6 the advertiser apparently intended to communicate something like the events portrayed in our ES magazine are of the same interest as the beauty/sexiness of the pictures portrayed in the magazine, thus suggesting that sexy women can be bought and enjoyed by consumers (most probably men) in the same way as the events reported. As all these assumptions seem to construct or defend a system of social relations in which women are characterised by denigratory stereotypical features (i.e. passive, powerless, valuable and desirable objects) whose role in society is to be purchased, used or consumed by men at this stage the interpretation will seem irrelevant to the addressee thus believing that the advertiser cannot have intended it. This seems to be weak evidence for the advertiser's informative intention as the sexist interpretation seems to be unrelated to the positive claims of the product and thus disregarded as a deliberate metaphor. This is a very clear example of an impositive asymmetrical metaphor in which the hearer is likely to refuse the imposition (cf. Goatly 1997: 129).

We concluded that this was a covert advertising gender metaphor as in the producer's informative intention was not mutually manifest, there was no optimal relevance and the interpreter used the visual cues as a reward to compensate his/ her processing effort in interpretation. In this case, as opposed to the metaphor in Plate 5, implicit reference was made to the image of the ad rather than an explicit one, thus acting as an input for further inferencing.

Regarding the number and percentage of advertising gender metaphors (i.e. cases of metaphorical gender, cultural gender metaphors and universal gender metaphors) in our sample we obtained the following data (Tables 1 and 2). 


\begin{tabular}{|c|c|c|}
\hline $\begin{array}{c}\text { TYPE OF } \\
\text { METAPHORS }\end{array}$ & $\begin{array}{c}\text { NUMBER OF } \\
\text { METAPHORS }\end{array}$ & \% METAPHORS \\
\hline Advertising metaphors & 1610 & 100 \\
\hline $\begin{array}{c}\text { Advertising gender } \\
\text { metaphors }\end{array}$ & 292 & 18.14 \\
\hline
\end{tabular}

Table 1. Number and percentage of advertising gender metaphors

\begin{tabular}{|c|c|c|}
\hline TYPE OF METAPHORS & $\begin{array}{c}\text { NUMBER OF } \\
\text { METAPHORS }\end{array}$ & \% METAPHORS \\
\hline Cases of metaphorical gender & 40 & 13.7 \\
\hline Universal gender metaphors & 39 & 13.36 \\
\hline Cultural gender metaphors & 213 & 72.94 \\
\hline
\end{tabular}

Table 2. Number and percentage of the different types of advertising gender metaphors

Concerning the number and percentage of overt and covert communicated advertising gender metaphors in our sample we obtained the following figures (Tables 3 to 6).

\begin{tabular}{|c|c|c|}
\hline $\begin{array}{c}\text { TYPE OF COMMUNICATED } \\
\text { ADVERTISING GENDER } \\
\text { METAPHORS }\end{array}$ & $\begin{array}{c}\text { NUMBER OF } \\
\text { METAPHORS }\end{array}$ & \% METAPHORS \\
\hline Overt & 184 & 63.01 \\
\hline Covert & 108 & 36.99 \\
\hline
\end{tabular}

Table 3. Number and percentage of overt and covert communicated advertising gender metaphors 


\begin{tabular}{|c|c|c|}
\hline $\begin{array}{c}\text { TYPE OF COMMUNICATED } \\
\text { CASES OF METAPHORICAL } \\
\text { GENDER }\end{array}$ & $\begin{array}{c}\text { NUMBER OF } \\
\text { METAPHORS }\end{array}$ & \% METAPHORS \\
\hline Overt & 26 & 65 \\
\hline Covert & 14 & 35 \\
\hline
\end{tabular}

Table 4. Number and percentage of overt and covert communicated cases of metaphorical gender

\begin{tabular}{|c|c|c|}
\hline $\begin{array}{c}\text { TYPE OF COMMUNICATED } \\
\text { UNIVERSAL GENDER } \\
\text { METAPHORS }\end{array}$ & $\begin{array}{c}\text { NUMBER OF } \\
\text { METAPHORS }\end{array}$ & \% METAPHORS \\
\hline Overt & 17 & 43.59 \\
\hline Covert & 22 & 56.41 \\
\hline
\end{tabular}

Table 5. Number and percentage of overt and covert communicated universal gender metaphors

\begin{tabular}{|c|c|c|}
\hline $\begin{array}{c}\text { TYPE OF COMMUNICATED } \\
\text { CULTURAL GENDER META- } \\
\text { PHORS }\end{array}$ & $\begin{array}{c}\text { NUMBER OF } \\
\text { METAPHORS }\end{array}$ & \% METAPHORS \\
\hline Overt & 149 & 69.95 \\
\hline Covert & 64 & 30.05 \\
\hline
\end{tabular}

Table 6. Number and percentage of overt and covert communicated cultural gender metaphors

As we can observe, there is a considerable number of overt communicated advertising gender metaphors (63.01\%) although the number of the covert communicated ones amounts to over a third of the total share of advertising gender metaphors (36.99\%). At this point we can comment that in our sample the presence of covert advertising gender metaphors is high enough to prove that covertness is not a minor strategy used by advertisers. With regard to the different types of advertising gender metaphors our data seem to prove that covertness is preferred for the most universal type of gender metaphors whereas the more specific ones usually rely 
on weak overt communication, probably because advertisers prefer to use some kind of ostension with the specific types of metaphors in order to ensure clarity for guiding the audience interpretation while retaining a higher degree of responsibility, therefore greater control over the audience's interpretations. Moreover, universal gender metaphors, as we saw (see section 3), are based on bodily experiences that are apparently universal and it is relatively easy to excuse and explain its use for discrimination on the grounds of our universal preconceptual experience.

As we applied the three criteria established above for determining whether advertising gender metaphors were communicated overtly or covertly we realised first that weak implicatures tend to be more "covert" than strong implicatures, second that covert metaphors are usually irrelevant to the nature of the product, and that the stimuli used by overt communicated advertising gender metaphors are explicit, therefore more dependent on semantic decoding whereas the ones used in covert communicated gender metaphors are implicit, and therefore more dependent on pragmatic inferences.

Next, considering that the "conventional-innovative" scale of metaphors seemed to be a determining factor for "overtness" or "covertness" we decided to explore whether conventional metaphors (i.e. those that derive a narrow range of strong implicatures) were weakly overt communicated whereas innovative metaphors (i.e. those that derive a wide range of weak implicatures) were covertly communicated and we found a perfect match between conventional advertising gender metaphors and "overtness" (with a high degree of weak communication) and innovative advertising gender metaphors and "covertness" (see Tables 7 to 10).

\begin{tabular}{|c|c|c|}
\hline $\begin{array}{c}\text { TYPE OF ADVERTISING } \\
\text { GENDER METAPHORS }\end{array}$ & $\begin{array}{c}\text { NUMBER OF } \\
\text { METAPHORS }\end{array}$ & \% METAPHORS \\
\hline Conventional & 184 & 63.01 \\
\hline Innovative & 108 & 36.99 \\
\hline
\end{tabular}

Table 7. Number and percentage of conventional and innovative advertising gender metaphors

\begin{tabular}{|c|c|c|}
\hline $\begin{array}{c}\text { TYPE OF CASES OF MET- } \\
\text { APHORICAL GENDER }\end{array}$ & $\begin{array}{c}\text { NUMBER OF } \\
\text { METAPHORS }\end{array}$ & \% METAPHORS \\
\hline Conventional & 26 & 65 \\
\hline Innovative & 14 & 35 \\
\hline
\end{tabular}

Table 8. Number and percentage of conventional and innovative cases of metaphorical gender 


\begin{tabular}{|c|c|c|}
\hline $\begin{array}{c}\text { TYPE OF UNIVERSAL } \\
\text { GENDER METAPHORS }\end{array}$ & $\begin{array}{c}\text { NUMBER OF } \\
\text { METAPHORS }\end{array}$ & \% METAPHORS \\
\hline Conventional & 17 & 43.59 \\
\hline Innovative & 22 & 56.41 \\
\hline
\end{tabular}

Table 9. Number and percentage of conventional and innovative universal gender metaphors

\begin{tabular}{|c|c|c|}
\hline $\begin{array}{c}\text { TYPE OF CULTURAL } \\
\text { GENDER METAPHORS }\end{array}$ & $\begin{array}{c}\text { NUMBER OF } \\
\text { METAPHORS }\end{array}$ & \% METAPHORS \\
\hline Conventional & 149 & 69.95 \\
\hline Innovative & 64 & 30.05 \\
\hline
\end{tabular}

Table 10. Number and percentage of conventional and innovative cultural gender metaphors

These data seem to prove that the wider the range of weakly communicated implicatures the greater the hearer's responsibility for constructing them, the more the poetic effect and the more creative the metaphor. Yet we realised that the most conventionalised metaphors used a narrow range of strongly communicated implicatures along with one or two weakly communicated assumptions, as in Plate 6 , thus making it clear that they are mostly examples of weak overt communication. On the whole, advertising gender metaphors apparently make ample use of weak communication by means of both weakly overt communicated advertising gender metaphors and covertly communicated advertising gender metaphors.

We then analysed the contribution of both overt-conventionalised advertising gender metaphors and covert-innovative advertising gender metaphors to the overall effect of the advert and discovered that:

(i) Overt-conventionalised advertising gender metaphors are hardly noticeable and therefore less likely to give rise to interactive interpretations since they are easily perceived as part of our mainstream culture, thus making them seem the natural way for us to structure our experience. They therefore enhance the credibility of the metaphor producer who retains a higher control over the audience's interpretations. 
(ii) Overt-conventionalised advertising gender metaphors achieve high cognitive salience and memorability. As they are perceived as closer to our initial expectations, they aid processing, store and retrieval and are subsequently easier to remember. They are therefore good at engaging the audience thought processes.

(iii) Overt-conventionalised advertising gender metaphors are effective in a cumulative way. As the reader does not see them as inconsistent with his or her initial expectations is not prompt to realign his/her expectations, thus achieving a long-lasting effect of conformity on the addressee.

(iv) Overt-conventionalised advertising gender metaphors are usually related to the product and its positive claims as they normally refer to the nature of the product, for example as something promoting or aiding physical beauty and/or attractiveness to others (i.e. bras, etc.) or products of a sexual nature (i.e. condoms, etc.).

(v) Overt-conventionalised advertising gender metaphors do not strengthen the emotional bond between the advertiser and the audience, thus cultivating a low level of intimacy.

(vi) Covert-innovative advertising gender metaphors are good attentiongrabbing and interest-raising devices since they are usually entertaining and puzzling.

(vii) Covert-innovative advertising gender metaphors are counterproductive in terms of salience and memorability. As they contradict our initial expectations, they do not aid processing, store and retrieval, thus subsequently making them difficult to remember.

(viii) Covert-innovative advertising gender metaphors have a temporary impact as they only temporarily mask the informative intention of the advertiser, always supposing that the addressee has spotted the "camouflaged" assumptions in the first place. At some point the reader is sure to find the weakly implicated assumptions of the metaphors inconsistent in terms of his or her expectations accordingly, making him/her decide, perhaps at a subconscious level, that a non-asymmetrical interpretation would be more appropriate. At this point, providing the reader has persevered this far, the informative intention would be recognised (and therefore the communication intention would be fulfilled).

(ix) Covert-innovative advertising gender metaphors are not normally related to the nature of the product. They contribute to the reward aspect of the advertisement.

(x) Covert-innovative advertising gender metaphors strengthen the emotional bond between the advertiser and the audience thus cultivating intimacy. 
Next, we have looked at the overt-conventionalised advertising gender metaphors and covert-innovative advertising gender metaphors to examine their discrimination against men and against women. The data of this study are shown on Tables 11 to 14 .

\begin{tabular}{|c|c|c|}
\hline $\begin{array}{c}\text { TYPE OF COMMUNICATED } \\
\text { ADVERTISING GENDER METAPHORS }\end{array}$ & $\begin{array}{c}\text { NUMBER OF } \\
\text { METAPHORS }\end{array}$ & $\begin{array}{c}\text { \% } \\
\text { METAPHORS }\end{array}$ \\
\hline $\begin{array}{c}\text { Overt-conventionalised advertising gender } \\
\text { metaphors that discriminate against men }\end{array}$ & 43 & 14.93 \\
\hline $\begin{array}{c}\text { Overt-conventionalised advertising gender } \\
\text { metaphors that discriminate against women }\end{array}$ & 159 & 54.45 \\
\hline $\begin{array}{c}\text { Covert-innovative advertising gender } \\
\text { metaphors that discriminate against men }\end{array}$ & 25 & 8.56 \\
\hline $\begin{array}{c}\text { Covert-innovative advertising gender } \\
\text { metaphors that discriminate against women }\end{array}$ & 65 & 22.26 \\
\hline
\end{tabular}

Table 11. Number and percentage of overt-conventionalised and covert-innovative advertising gender metaphors that discriminate against men and women

\begin{tabular}{|c|c|c|}
\hline $\begin{array}{c}\text { TYPE OF COMMUNICATED CASES } \\
\text { OF METAPHORICAL GENDER }\end{array}$ & $\begin{array}{c}\text { NUMBER OF } \\
\text { METAPHORS }\end{array}$ & $\begin{array}{c}\% \\
\text { METAPHORS }\end{array}$ \\
\hline $\begin{array}{c}\text { Overt-conventionalised cases of } \\
\text { metaphorical gender that discriminate } \\
\text { against men }\end{array}$ & 10 & 83.33 \\
\hline $\begin{array}{c}\text { Overt-conventionalised cases of } \\
\text { metaphorical gender that discriminate } \\
\text { against women }\end{array}$ & 26 & 92.86 \\
\hline $\begin{array}{c}\text { Covert-innovative cases of metaphorical } \\
\text { gender that discriminate against men }\end{array}$ & 2 & 16.67 \\
\hline $\begin{array}{c}\text { Covert-innovative cases of metaphorical } \\
\text { gender that discriminate against women }\end{array}$ & 2 & 7.14 \\
\hline
\end{tabular}

Table 12. Number and percentage of overt-conventionalised and covert-innovative cases of metaphorical gender that discriminate against men and women 


\begin{tabular}{|c|c|c|}
\hline $\begin{array}{c}\text { TYPE OF COMMUNICATED } \\
\text { UNIVERSAL GENDER METAPHORS }\end{array}$ & $\begin{array}{c}\text { NUMBER OF } \\
\text { METAPHORS }\end{array}$ & $\begin{array}{c}\text { \% } \\
\text { METAPHORS }\end{array}$ \\
\hline $\begin{array}{c}\text { Overt-conventionalised universal } \\
\text { gender metaphors that discriminate } \\
\text { against men }\end{array}$ & 8 & 44.44 \\
\hline $\begin{array}{c}\text { Overt-conventionalised universal } \\
\text { gender metaphors that discriminate } \\
\text { against women }\end{array}$ & 7 & 33.33 \\
\hline $\begin{array}{c}\text { Covert-innovative universal gender } \\
\text { metaphors that discriminate against } \\
\text { men }\end{array}$ & 10 & 55.56 \\
\hline $\begin{array}{c}\text { Covert-innovative universal gender } \\
\text { metaphors that discriminate against } \\
\text { women }\end{array}$ & 14 & 66.67 \\
\hline
\end{tabular}

Table 13. Number and percentage of overt-conventionalised and covert-innovative universal gender metaphors that discriminate against men and women

\begin{tabular}{|c|c|c|}
\hline $\begin{array}{c}\text { TYPE OF COMMUNICATED } \\
\text { CULTURAL GENDER METAPHORS }\end{array}$ & $\begin{array}{c}\text { NUMBER OF } \\
\text { METAPHORS }\end{array}$ & $\begin{array}{c}\text { \% } \\
\text { METAPHORS }\end{array}$ \\
\hline $\begin{array}{c}\text { Overt-conventionalised cultural } \\
\text { gender metaphors that discriminate } \\
\text { against men }\end{array}$ & 23 & 60.53 \\
\hline $\begin{array}{c}\text { Overt-conventionalised cultural } \\
\text { gender metaphors that discriminate } \\
\text { against women }\end{array}$ & 126 & 72 \\
\hline $\begin{array}{c}\text { Covert-innovative cultural gender } \\
\text { metaphors that discriminate against men }\end{array}$ & 15 & 28.47 \\
\hline $\begin{array}{c}\text { Covert-innovative cultural gender } \\
\text { metaphors that discriminate against } \\
\text { women }\end{array}$ & 49 & \\
\hline
\end{tabular}

Table 14. Number and percentage of overt-conventionalised and covert-innovative cultural gender metaphors that discriminate against men and women 
As can be seen overt-conventionalised advertising gender metaphors turned out to be more sexist than covert-innovative advertising gender metaphors, being this trend remarkably noticeable in those cases of specific advertising gender metaphors (i.e. cases of metaphorical gender and universal gender metaphors) that discriminate against women. This may be explained in terms of the different advantages that overt-communicated advertising gender metaphors offer to the overall effect of the advert. As we saw before, although overt conventionalised advertising gender metaphors are hardly noticeable and less likely to give rise to interactive interpretations on the part of the audience, they are perceived as a natural part of our mainstream culture, they also enhance the credibility of the metaphor producer, they achieve high cognitive salience and memorability and are effective in a cumulative way, thus having a long-lasting effect of conformity on the addressee. In sum, they work better than covert-innovated advertising gender metaphors at engaging and controlling the audience thought processing, steering their viewpoints in a certain direction.

Concerning the different types of advertising gender metaphors it appears, as we have just mentioned, that the more specific types of advertising gender metaphors, namely the cases of metaphorical gender and cultural gender metaphors are more overtly communicated when they introduce discrimination against women whereas covert communication is preferred when they discriminate against men, probably because, as we are arguing, there seems to be a continuum of cases of overt-conventionalised advertising gender metaphors and covert-innovative advertising gender metaphors. Most overt-conventionalised metaphors that discriminate against women today are likely to have started as covert-innovative advertising gender metaphors and then found successful in steering the thoughts of the audience in a certain direction, thus becoming conventionalised and, subsequently, overtly communicated. Both poles of the continuum seem to be but successive stages of a continuous process by which advertisers may perpetrate or break certain evaluation on gender relations. Hence advertising gender metaphors that discriminate against women are normally seen as part of our mainstream culture while discrimination against men is still puzzling and therefore yet covertly communicated.

As shown in Table 12 the cases of sexist covert-innovative cases of metaphorical gender that discriminate against men (16.67\%) double those that discriminate against women $(7.14 \%)$ whereas the percentages for discrimination against men $(83.33 \%)$ and women (92.86\%) are very similar in the case of overt-conventionalised cases of metaphorical gender. This can be explained by the fact that cases of metaphorical gender are very standardised and preferably overtly communicated perhaps because they are expected as part of the "commoditisation process" or "theory of metaphorical commodification" that typically impregnates the genre of advertising. 
In Table 13 we can observe that the instances of covert-innovative universal gender metaphors that discriminate against women (66.67\%) double those that are overt-conventionalised that discriminate against them (33.33\%) whereas we find more similar percentages in the case of overt-conventionalised universal gender metaphors that discriminate against men (55.56\%) and covert-innovative universal gender metaphors that discriminate against them (66.67\%). The fact that covertness prevails in both cases seems to be justified by the very indirect nature of image schemas that underlie universal gender metaphors. As they go easily unnoticed they have to be used sparingly since a strong use would attract the audience attention and make the advertiser intention all too manifest.

As can be seen in Table 14, and similarly to the cases of metaphorical gender, in our sample the percentages of overt-conventionalised cultural gender metaphors that discriminate against men (60.53\%) are very similar to those that discriminate against women (72\%). This seems to be justified in this case by the fact that the most sexist cultural gender metaphors that discriminate against men are rooted in traditional feminine stereotypes (i.e. beauty, attractiveness, emotion, etc.) that are now beginning to be applied to men. They apparently were already conventionalised in their use and seem to keep their naturalness when they are now applied to men. On the other hand, and also very similar to the cases of metaphorical gender in our sample, there are only $28 \%$ sexist innovative cultural gender metaphors that discriminate against women. This may be explained by the fact that traditional masculine stereotypes (i.e. power, strength, etc.) that underlie these metaphors have traditionally been considered positive, and this is still the case when they are now applied to women, except for a few ones (i.e. large sexual needs, etc.) that still seem to keep negative overtones when applied to women.

\section{CONCLUSION}

Covert communication along with weak overt communication has an important influence on the choice, specification and interpretation of advertising gender metaphors. Both types of weak communication allow the reader to hint at nonneutral assumptions of gender without being vulnerable to the accusation of strongly backing them. Therefore we argue for the idea that a satisfactory definition of covert communication would thus have to accommodate the fact that weak overt communication and covert communication are different clines of the overt-covert communicative continuum.

Yet, whilst it is essential to recognise the idea of the overt-covert communication continuum, it is equally important, from the point of view of theorising advertising and the discursive cognitive-pragmatic theorising of advertising metaphors and 
gender, to recognise the overall importance of covert communication. On the one hand, the use of covert communication in advertising corresponds to two concrete reasons: (1) to meet the first two criteria of the AIDA formula and (2) to improve social relations with the audience (Tanaka 1999: 62). On the other hand, advertisers take advantage of covertness in some of their metaphors to communicate messages of particular sensitivity (i.e. sex, gender, snobbery, etc.) which they do not wish to do so openly, thus escaping any responsibility for doing so and avoiding the negative social relations emanating from the public. The audience also benefits from becoming more involved in the advert interpretation process.

Advertising gender metaphors are ideological metaphors in which the conceptual mapping(s) that is(are) projected from the source to the target domain may create and/or reflect some kind of discrimination against men or women. They have verbal, non-verbal or multimodal realisations in discourse and have the potential to give rise to sexist interpretations that are often covertly or weakly overtly communicated. In the discourse of English advertising there are three different types of gender metaphors: "cases of metaphorical gender", "universal gender metaphors" and "cultural gender metaphors". These types, rather than appearing in isolation in single ads, very often co-occur giving rise to a complex network of gender relations within numerous adverts.

Regarding "overtness-covertness" in advertising gender metaphors we have observed in our study of advertising gender metaphors in British Cosmopolitan that metaphor producers of advertising gender metaphors use a scale of overt and covert communicated gender metaphors to impose an asymmetrical gender value system on their audience. Covertness is preferred for the most universal type of advertising gender metaphor whereas the more specific ones usually rely on weak communication probably because weak ostension allows advertisers to ensure clarity for guiding the audience interpretation while retaining a higher degree of responsibility, therefore greater control over the audience's interpretations. In addition, we have found in our sample under study that the "conventionalinnovative scale of metaphors" is a determining factor for overtness or covertness as there is a perfect match between those advertising gender metaphors that are weakly overt communicated and conventional advertising gender metaphors and between those advertising gender metaphors that are covertly communicated and innovative advertising gender metaphors.

In terms of discrimination overtly-communicated conventionalised advertising gender metaphors turned out to be more sexist than covertly communicated innovative advertising gender metaphors, being this trend remarkably noticeable in those cases of specific advertising gender metaphors that discriminate against 
women. Apparently advertisers prefer weakly overt communication for the obvious advantages that this type of communication has for the overall advert. On the whole, weak overt communicated advertising gender metaphors work better than covert communicated advertising gender metaphors at engaging and controlling the audience thought. In addition, it may well be the case that those metaphors that are now communicated overtly had started as innovative ones, thus being covertly communicated and then found successful in changing the thoughts of the audience. Therefore both poles of the continuum would be but successive stages of a continuous process by which advertisers may perpetrate or break certain evaluations on gender relations.

Concerning the different types of advertising gender metaphors in our sample it appears that the more specific types of advertising gender metaphors, namely the cases of metaphorical gender and cultural gender metaphors are more overtly communicated when they introduce discrimination against women whereas covertness is preferred when they discriminate against men. This seems to prove that discrimination against women is still seen as part of our mainstream culture whereas discrimination against men is not yet so much conventionalised. The most universal type of advertising gender metaphors rely on covertness to discriminate against men or women due to the inherent "covert" nature of image schemas that sustain this type of metaphor.

In short, as our study has proved, weak overt communication allow the advertiser to "have his cake and eat it" (cf. Tanaka 1999: 58) when it comes to advertising gender metaphors that are sexist thus contributing to the view that weak overt communication plays a very important role in today advertising, as suggested by Crook and recent cognitive and social psychology and audience reception studies. Weak overtness seems indeed to be more insidious than covert communication to introduce discrimination, mostly against women, because it allows the metaphor producer to retain a higher level of control over the audience interpretation process while creating or maintaining a non-neutral gender value system. Covertness, on the other hand, is mostly used to discriminate against men, although this discrimination works mostly as an attention-grabbing and interestraising technique that has a temporary and short-lived effect. Time will say whether these now covertly communicated advertising gender metaphors that discriminate against men become conventionalised and thus part of our mainstream culture.

\section{REFERENCES}

Barcelona Sánchez, A. 1997. "Clarifying and Applying the Notions of Metaphor and Metonymy within Cognitive Linguistics”. ATLANTIS XIX (1): 21-48. 
Bogart, L. 1990. Strategy in Advertising: Matching Media and Messages to Markets and Motivations. Lincolnwood, IL: NIC.

Borchers, T. A. 2005 (2002). Persuasion in the Media Age. Second edition. Oxford: Oxford University Press.

Cabe, P. A. 1999. "Review of Pictorial Metaphor in Advertising (by Charles Forceville. 1996)". Metaphor E Symbol 14 (3): 229-238.

Cook, G. 1992. The Discourse of Advertising. London: Routledge.

Cortés de los Ríos, M. E. 2001. Nuevas perspectivas lingüísticas en la publicidad impresa anglosajona. Almería: Universidad de Almería, Servicio de Publicaciones.

Crook, J. 2004. "On covert communication in advertising". Journal of Pragmatics 36: $715-738$.

De Chenecey, S. 2000. "The New Persuaders". Admap 35 (8): 35-37.

Deighton, J. 1985. "Rhetorical Strategies in Advertising". Advances in Consumer Research. Vol. 12. Ed. Morris Holbrook and Elizabeth Hirschmen. Ann Arbor, MJ: Association for Consumer Research. 432-436.

Dingena, M. 1994. The Creation of Meaning in Advertising. Tinbergen Institute Research Series, No 62: Amsterdam: Thesis Publishers.

Durand, J. 1987. "Rhetorical Figures in the Advertising Image". Marketing and Semiotics: New Directions in the Study of Signs for Sale. Ed. Jean Umiker-Sebeok. New York: Mouton. 295-318.

Dyer, G. 1984. Advertising as Communication. London: Methuen.

Emanatian, M. 1995. "Metaphor and the expression of emotion: the value of crosscultural perspectives”. Metaphor and Symbolic Activity 10: 163-182.

Emanatian, M. 1999. "Congruence by degree. On the relation between metaphor and cultural models". Metaphor and Symbolic Activity. Ed. Raymond W. Gibbs Jr. and Gerard Steen. Amsterdam/Philadelphia: John Benjamins. 205-218.

Fairclough, N. 1989. Language and Power. London: Longman.

Forceville, C. 1991. "Verbopictorial metaphor in advertisements". Parlance 3: 7-10.

Forceville, C. 1994. "Pictorial metaphor in advertisements". Metaphor and Symbolic Activity 9: 1-29.

Forceville, C. 1996. Pictorial metaphor in advertising. London: Routledge.

Forceville, C. 1999. “The Metaphor 'COLIN IS A CHILD' in Ian McEwan's, Harold Pinter's, and Paul Schrader's The Comfort of Strangers". Metaphor and Symbol 14 (3): 179-198.

Forceville, C. 2000. "Compasses, beauty queens and other POs: Pictorial metaphors in computer advertisements". Hermes, Journal of Linguistics 24: 31-55. 
Forceville, C. 2002. "The identification of target and source in pictorial metaphors". Journal of Pragmatics 34: 1-14.

Gibbs, R. W. Jr. 1999. "Taking metaphor out of our heads and putting it into the cultural world. Metaphor in Cognitive Linguistics. Eds. Raymond W. Jr. and Gerard Steen. Amsterdam/Philadelphia: John Benjamins. 145-166.

Goatly, A. 1997. The Language of Metaphors. London and New York: Routledge.

Holland, D. and N. Quinn, eds. 1987. Cultural Models in Language and Thought. Cambridge: Cambridge University Press.

Howard, D. J. 1990. "Rhetorical Question Effects on Message Processing and Persuasion: The Role of Information Availability and the Elicitation of Judgment". Journal of Experimental Social Psychology, 26 (May): 217-239.

Johnson, M. 1987. The Body in the Mind. The Bodily Basis of Meaning, Reason and Imagination. Chicago: University of Chicago Press.

Jones, J. P. 1997. "Is Advertising Still Salesmanship?". How Advertising Works. Ed. J. Jones. London: Sage. 82-95.

Jones, J. P. 1999. "Hierarchies of effect: advertising theories". The Advertising Business. Ed. J. Jones. London: Sage. 219-225.

King, B. 1989. "The Conceptual Structure of Emotional Experience in Chinese". Ph. D. dissertation. Ohio State University.

Kövecses, Z. 1990. Emotion Concepts. New York: Springer.

Kövecses, Z. 1999. "Metaphor: Does it constitute or reflect cultural models?". Metaphor in Cognitive Linguistics. Ed. Raymond W. Gibbs and Gerard Steen. Amsterdam/Philadelphia: John Benjamins. 167-188.

Kövecses, Z. 2002. Metaphor: A Practical Introduction. New York: Oxford University Press.

Krzeszowski, T. 1990. "The axiological aspect of cognitive models". Meaning and Lexicography. Eds. J. Tomasczcyk and B. Lewandoska. Amsterdam/Philadelphia: John Benjamins. 315-365.

Krzeszowski, T. 1993. "The axiological parameter in preconceptual image schemata". Conceptualizations and Mental Processing in Language. Eds. R. A. Geiger and Rudzka-Ostyn. Berlin: Mouton de Gruyter. 307-330.

Kwanka, B. 1993. "Diskurstruktur und Diskursstratigien in englischen Verkaufsgesprächen”. M. A. thesis. München. (Unpublished MS).

Lakoff, G. 1987. Women, Fire and Dangerous Things. What Categories Reveal About the Mind. Chicago: Chicago University Press.

Lakoff, G. 1993. "The contemporary theory of metaphors". Metaphor and Thought. Ed. Andrew Ortony. Second edition. Cambridge: Cambridge University Press. 202-251. 
Lakoff, G. and M. Johnson. 1980. Metaphors We Live By. Chicago: University of Chicago Press.

Lakoff, G. and Z. Kövecses. 1987. "The cognitive model of Anger inheritent in American English". Cultural Models in Language and Thought. Eds. Dorothy Holland and Naomi Quinn. Cambridge: Cambridge University Press. 195-221.

Lakoff, G. and M. Turner. 1989. More than Cool Reason: A Field Guide to Poetic Metaphor. Chicago: University of Chicago Press.

Leigh, J. H. 1994. "The Use of Figures of Speech in Print Ad Headlines". Journal of Advertising 123 (June): 17-34.

Matsuki, K. 1995. "Metaphor of anger in Japanese". Language and the Cognitive Construal of the World. Eds. John R. Taylor and Robert E. Maclaury. Berlin: Mouton. 137-151.

McGuire, J. M. 1999. "Pictorial metaphors. A reply to Sedivy". Metaphor E Symbol 14(4): 293-302.

McGuire, W. J. 2000. "Standing on the Shoulders of Ancients: Consumer Research, Persuasion and Figurative Language". Journal of Consumer Research 27: 109-114.

McQuarrie, E. F. and D. Glen Mick. 1992. "On Resonance: A Critical Pluralistic Inquiry into Advertising Rhetoric". Journal of Consumer Research 19: 180-197.

McQuarrie, E. F. and D. Glen Mick. 1996. "Figures of Rhetoric in Advertising Language". Journal of Consumer Research 22: 424-437.

McQuarrie, Edward F. and David Glen Mick. 1999. "Visual Rhetoric in Advertising: Text-Interpretive, Experimental and Reader-Response Analyses". Journal of Consumer Research 26: 37-54.

McQuarrie, E. F. and D. Glen Mick. 2003. "Visual and Verbal Rhetorical Figures under Directed Processing versus Incidental Exposure to Advertising". Journal of Consumer Research 29: 579-587.

Messaris, P. 1997. Visual Persuasion: The Role of Images in Advertising. Thousand Oaks. CA: Sage.

Neumann, C. 2001. "Is Metaphor Universal? Cross-Language Evidence from German and Japanese”. Metaphor \& Symbol. 16 (1 \& 2): 123-142.

Pauwels, A. 1998. Women Changing Language. London and New York: Longman.

Quinn, N. 1991. "The cultural basis of metaphor". Metaphor: The Theory of Tropes in Anthropology. Ed. Beyon. Stanford: Stanford University Press.

Sánchez Corral, L. 1991. Retórica y sintaxis de la publicidad (Itinerarios de la persuasión). Córdoba: Universidad de Córdoba.

Sánchez Corral, L. 1997. Semiótica de la Publicidad. Narración y Discurso. Madrid: Editorial Síntesis. 
Scott, L. M. 1994. "Images in Advertising: The Need for a Theory of Visual Rhetoric". Journal of Consumer Research 21 (September): 252-273.

Smith, N. and D. Wilson. 1992. "Introduction". Lingua 87: 1-10.

Sperber, D and D. Wilson. 1995 (1986). Relevance: Communication and Cognition. Second edition. Oxford UK and Cambridge USA: Blackwell.

Sutherland, M. 2001. "Ad Strategies for Brand Warfare". Admap 36 (1): 14-16.

Sutherland, M. and A. Sylvester. 2000. Advertising and the Mind of the Consumer. London. Kogan Page.

Talbot, M. 1992. "The Construction of Gender in a Teenage Magazine". Critical Language Awareness. Ed. Norman Fairclough. London and New York: Longman: 174-199.

Tanaka, K. 1999 (1994). Advertising Language: A Pragmatic Approach to Advertisements in Britain and Japan. London: Routledge.

Umiker-Sebeok, J. 1996. "Power and the Construction of Gendered Spaces". International Review of Sociology 6 (3): 389-403. Available: <http://www.slis. indiana.edu/faculty/umikerse/papers/power.html

Ungerer. F. 2000. "Muted metaphors and the activation of metonymies in advertising". Metaphor and Metonymy at the Crossroads. A Cognitive Perspective. Ed. Antonio Barcelona Sánchez. Berlin and New York: Mouton de Gruyter. 321-340.

Velasco Sacristán, M. 1999. "Publicidad y metáfora: Análisis lingüístico de las metáforas de los eslóganes de anuncios de perfumes aparecidos en las ediciones hispana y británica de Cosmopolitan 1998". Unpublished M. A. dissertation. Universidad de Valladolid (Spain).

Velasco Sacristán, M. 2003. "Publicidad y Género: Propuesta, diseño y aplicación de un modelo de análisis de las metáforas de género en la publicidad impresa en lengua inglesa". Ph D. thesis. Universidad de Valladolid. Available: http:// wwwlib.com/dissertations/fullcit/3076827 (ISBN: O-493-99159-X).

Velasco Sacristán, M. 2005. "A critical cognitive-pragmatic approach to advertising gender metaphors". Intercultural Pragmatics 2-3: 219-252.

Velasco Sacristán, M., P. A. Fuertes Olivera and E. Samaniego Fernández. 2005. "La metáfora cultural de género en el discurso publicitario. Ejemplo de proyección metafórica de origen metonímico". Cognitive and Discourse Approaches to Metaphor and Metonymy. Eds. J. L. Otal Campo, I. Navarro I Ferrando and B. Bellés Fortuño. Universitat Jaume I: Castellón (Spain): 157-173.

Velasco-Sacristán, M. and P. A. Fuertes-Olivera. 2006. "Towards a critical cognitivepragmatic approach to gender metaphors in advertising English". Journal of Pragmatics 38: 1982-2002. 
Vestergaard, T. and K. Schrøder. 1985. The Language of Advertising. Oxford: Blackwell. Yu, N. 1995. "Metaphorical expressions of anger and happiness in English and Chinese". Metaphor and Symbolic Activity 10: 59-92.

Zaltman, G. and R. Coulter. 1995. "Seeing the voice of the consumer: metaphorbased advertising research". Journal of Advertising Research 35/4: 35-51. 